\title{
CARE STICK DAN CORE PADDLE: MEDIA PEMBELAJARAN PENDIDIKAN JASMANI ADAPTIF UNTUK SISWA DISABILITAS
}

\author{
Fajar Hidayatullah ${ }^{* 1}$, Khoirul Anwar ${ }^{2}$, Ruski $^{3}$ \\ STKIP PGRI Bangkalan, Indonesia*1,23 \\ Email: fajar@stkippgri-bkl.ac.id ${ }^{* 1}$, khoirul@ stkippgri-bkl.ac.id ${ }^{2}$, ruski@ stkippgri-bkl.ac.id ${ }^{3}$
}

Received: 25 June 2020; Accepted 03 November 2020; Published 04 December 2020

Ed 2020; 5(2): 199-214

\begin{abstract}
ABSTRAK
Pengembangan media pembelajaran olahraga ini berupa tongkat estafet dan bat tenis meja untuk mengatasi masalah pembelajaran gerak siswa Sekolah Luar Biasa Negeri Keleyan. Media pembelajaran yang aman karena akan digunakan siswa yang sering hiperaktif, nyaman digunakan untuk siswa tunadaksa dan menarik perhatian siswa dengan keunikannya. Metode penelitian pengembangan yang menggunakan pendekatan kuantitatif deskriptif diterapkan dengan penyesuaian terhadap kondisi pandemi COVID-19 sehingga jumlah sampel tidak memungkinkan dengan jumlah banyak serta dibuat terpisah untuk menjaga kesehatan dan keselamatan seluruh pihak terkait di dalamnya. Teknik pengambilan sampel menggunakan purposive sampling dengan rincian total 60 sampel terbagi dalam 3 tahapan pengembangan dan analisis deskriptif dilakukan untuk menyimpulkan hasil pengembangan. Hasil penelitian berupa tongkat estafet dengan karakteristik aman, nyaman digunakan dan menarik perhatian telah tercapai didukung dengan sebagian besar responden yang memberikan tanggapan positif terhadap hasil pengembangan CARE Stick dapat diterima dengan baik sebagai tongkat estafet yang dimodifikasi sesuai kebutuhan siswa Sekolah Luar Biasa Negeri Keleyan. Begitu pula dengan CORE Paddle yang merupakan modifikasi bat tenis meja dapat diterima dengan baik sebagai hasil pengembangan yang dapat memenuhi kebutuhan siswa Sekolah Luar Biasa Negeri Keleyan.
\end{abstract}

Kata Kunci: Care Stick; Core Paddle; Media Pembelajaran; Disabilitas

\section{CARE STICK AND CORE PADDLE: LEARNING MEDIA OF ADAPTIVE PHYSICAL EDUCATION FOR DISABILITY STUDENTS}

\begin{abstract}
The development of this sports learning media in the form of a relay baton and table tennis bat to solve the problem of motion learning for students at State Special School Keleyen. It is safe learning media because it will be used by students who are often hyperactive, it is comfortable to use for students with physical disabilities and to attract students' attention with students' uniqueness. The development research method uses a descriptive quantitative approach applied with adjustments to the COVID-19 pandemic condition so that numbers of samples do not enable with large amount and are made separately to maintain the health and safety of all related parties in it. The sampling technique uses purposive sampling with details of a total of 60 samples divided in 3 development stages and descriptive analysis is conducted to conclude the development result. The research results shows the form of a relay stick with the safe characteristics, it is comfortable to use and attracting attention have been reached supported by the majority of respondents that give positive responses to the results of the development of the CARE Stick can be accepted well as a modified relay stick based on the needs of Keleyan Special School students. Likewise, the CORE Paddle is as a modification of table tennis bat that can be accepted well as a result of development that can fulfill the needs of Keleyan State School students.
\end{abstract}

Keyword: Care Stick; Core Paddle; Learning Media; Disabilities

Copyright (C) 2020, Journal Sport Area

DOI: https://doi.org/10.25299/sportarea.2020.vol5(2).5185

How To Cite: Hidayatullah, F., Anwar, K., \& Ruski. (2020). Care Stick dan Core Paddle: Media Pembelajaran Pendidikan Jasmani Adaptif Untuk Siswa Disabilitas. Journal Sport Area, 5(2), 199-214. 


\section{PENDAHULUAN}

Kualitas pendidikan jasmani adaptif ataupun pendidikan inklusi yang dikhawatirkan masih belum memadai sesuai kebutuhan siswa telah menjadi keprihatinan tersendiri oleh beberapa pihak terkait baik guru maupun peneliti sebelumnya. Kurang memadainya kualitas pendidikan dari infrastruktur, guru yang memadai karena penugasan kerja tidak sesuai adalah sebuah diskriminasi bagi guru dalam kebutuhan pendidikan khusus mengakibatkan ketidakpercayaan keluarga siswa dalam sistem pendidikan (Pappas, Papoutsi, \& Drigas, 2018), peralatan pembelajaran yang spesifik, kesesuaian pendampingan pembelajaran dan intens serta penggunaan strategi pembelajaran khusus oleh guru harus menjadi perhatian khusus (Hettiaarachi, Ranaweera, Walisundara, Daston-Attanayake, \& Das, 2018), perihal ini sesuai dengan temuan penelitian sebelumnya bahwa guru-guru prihatin dengan ketidaktersediaan materi pembelajaran dan perlengkapan yang memadai bagi inklusi (Chhabra, Srivastava, \& Srivastava, 2010; Friend \& Bursuck, 2012; Oswald \& Swart, 2011).

Sesuai hasil analisis kebutuhan ditemukan permasalahan kurang sesuainya alat olahraga yang digunakan sebagai media pembelajaran PJOK di Sekolah Luar Biasa Negeri Keleyan Kabupaten Bangkalan. Kurang sesuainya alat olahraga pertama adalah penggunaan tongkat estafet dalam pembelajaran memiliki keamanan yang kurang memadai terutama saat digunakan oleh siswa tuna grahita terkadang histeris dikhawatirkan melemparkan tongkat estafet dengan bahan keras pada temannya. Selain itu tongkat estafet yang konvensional sering merosot dari genggaman saat dipegang oleh siswa dengan tunadaksa karena kemampuan menggenggamnya memiliki keterbatasan gerak. Tongkat estafet konvensional yang biasa digunakan juga perlu dimodifikasi supaya menimbulkan ketertarikan bagi siswa. Permasalahan pada sekolah luar biasa berikutnya adalah bat permainan tenis meja yang tidak sesuai keadaan siswa berkebutuhan khusus pada umumnya memiliki kekurangan dalam keterampilan psikomotornya sehingga kemampuannya untuk memukul bola tenis meja sering meleset. Permasalahan ini diharapkan mitra untuk menjadi bahan pengembangan dengan memperbesar luas penampang kepala bat tenis meja dari ukuran biasanya sehingga diharapkan dapat meningkatkan persentase perkenaan bola pada bat pemukul. Anak-anak dengan kelainan perkembangan dan cacat mental memiliki keterampilan motorik halus yang lebih buruk (Jeoung, 2018), Seperti contohnya pada siswa dengan autisme menunjukkan keterlambatan gerak (Bhat, Landa, \& Galloway, 2011; Liu \& Breslin, 2013; MacDonald, Lord, \& Ulrich, 2014; Staples \& Reid, 2010; Martika, 2020), belum ada penjelasan yang membedakan secara spesifik untuk siswa dengan disabilitas gerak atau siswa dalam pendidikan jasmani adaptif sehingga pengembangan fasilitas dan peralatan memadai untuk melayani siswa menjadi tantangan tersendiri untuk dikembangkan (Morley, Bailey, Tan, \& Cooke, 2005).

Pendidikan jasmani memiliki berbagai peranan penting dalam mempengaruhi perkembangan siswa berkebutuhan khusus melihat berbagai pengaruh positif yang dapat tercapai dalam pelaksanaannya. Kebiasaan siswa dengan keterbatasan mental yang aktif dalam berolahraga dibandingkan dengan siswa yang tidak berolahraga menunjukkan bahwa siswa yang berolahraga menunjukkan lebih banyak perilaku interaksi sosial (Kızar, Dalkılıç, Uçan, Mamak, \& Yiğit, 2015; Kielhofner \& Miyake, 1981) melalui pendidikan olahraga juga akan memfasilitasi kesadaran bahwa disabilitas juga dapat beraktivitas olahraga seperti orang lain sehingga dapat memberi gambaran positif kepada siswa mengenai konsep "sport in all its forms for all the people" (Foley, Tindal, Lieberman, \& Kim, 2007) disimpulkan pula bahwa meyakinkan penyandang disabilitas 
untuk terlibat dalam aktivitas pengembangan olahraga dapat berkontribusi dalam memperbaiki taraf hidup penyandang disabilitas (Devine, Carrol, Naivalu, Seru, Baker, Bayak-Bush, James, Larcombe, Brown, \& Marella, 2017). Dengan berbagai kesimpulan tersebut dapat diyakini bahwa kegiatan berolahraga bagi siswa berkebutuhan khusus (disabilitas) dapat menjadi salah satu cara dalam membentuk tumbuh kembang siswa terutama dalam sekolah luar biasa melalui pembiasaan aktivitas olahraga. Penelitian sebelumnya pernah dilakukan modifikasi permainan lari estafet untuk siswa Sekolah Luar Biasa dengan merubah penggunaan tongkat estafet dengan bola sebagai penggantinya untuk meningkatkan gerak dasar manipulatif pada siswa tunagrahita (Ardiansyah \& Tuasikal, 2016). Pengembangan media pembelajaran bagi pendidikan jasmani adaptif masih menjadi aspek yang membutuhkan banyak perhatian lebih mendalam lagi dengan sangat dinamisnya kebutuhan siswa terutama di sekolah luar biasa. Terdapat berbagai pertimbangan dalam mengembangkan olahraga adaptif memiliki keterbatasan fasilitas, peluang dan pemenuhan kebutuhan yang memadai bagi siswa yang berkebutuhan khusus (Lastuka \& Cottingham, 2015; Bano, Akhter, \& Anjum, 2013), dapat disimpulkan bahwa pendidikan jasmani bagi siswa dengan disabilitas dapat dilakukan modifikasi media pembelajaran sesuai kebutuhan sehingga siswa disabilitas dapat lebih mudah atau tertarik untuk berpartisipasi (Erianti \& Sari, 2018).

Penelitian pengembangan ini dilaksanakan untuk menyelesaikan permasalahan kesesuaian tongkat estafet dan bat tenis meja dengan keterbatasan yang dimiliki oleh siswa Sekolah Luar Biasa Negeri Keleyan. Pengembangan media pembelajaran olahraga bagi siswa berkebutuhan khusus merupakan hal yang penting dilakukan dalam menyesuaikan media pembelajaran dengan berbagai karakteristik keterbatasan siswa. Departemen Pendidikan dan Kebudayaan pada tahun 1993 menyarankan agar guru Penjas kreatif bersama siswa untuk melengkapi peralatan yang dibutuhkan tongkat estafet dengan menggunakan kayu bulat yang dipotong sesuai dengan ukuran tongkat estafet dapat dilakukan untuk memenuhi kebutuhan (Depdikbud, 1993). Penyesuaian tongkat estafet yang dijelaskan oleh depdikbud tersebut tentunya belum sepenuhnya dapat mewakili kebutuhan siswa Sekolah Luar Biasa Negeri Keleyan serta membutuhkan pengembangan lebih lanjut karena telah lebih dari 10 tahun yang lalu dikembangkan.

\section{METODE PENELITIAN}

Pendekatan penelitian pengembangan menjadi karakter utama dalam penelitian ini dalam mengembangkan media pembelajaran pendidikan jasmani olahraga dan kesehatan bagi siswa Sekolah Luar Biasa Negeri Keleyan. Analisis kebutuhan dilakukan sebelum pelaksanaan kegiatan yang menyimpulkan kebutuhan pengembangan media pembelajaran tongkat estafet dan bat tenis meja sesuai kebutuhan siswa dengan berbagai kekhususan berbeda. Model pengembangan Borg and Gall yang diintegrasikan dengan model pengembangan Owen (Aka, 2019), model pengembangan yang digunakan dalam penelitian ini dengan 12 tahapan pelaksanaan antara lain pengumpulan informasi awal, perencanaan, pengembangan desain awal produk, evaluasi ahli, revisi sesuai masukan ahli, uji coba awal, revisi produk utama, uji coba produk utama, revisi produk operasional, uji coba produk operasional, revisi produk final, diseminasi dan implementasi.

Total 60 sampel dalam penelitian ini menggunakan teknik pengambilan sampel purposive sampling dan terbagi dalam 3 tahapan uji coba dimana sampel dalam 
penelitian ini memiliki ciri-ciri khusus adalah mereka yang memiliki pengalaman mengajar dan berinteraksi dengan siswa berkebutuhan khusus. Atas hal tersebut tim peneliti mengundang responden dari luar sekolah untuk melakukan uji coba sebagai sampel penelitian berasal dari kalangan guru yang menyatakan pernah memiliki pengalaman mengajar siswa Sekolah Luar Biasa serta guru pada Sekolah Luar Biasa Negeri Keleyan yang menjadi mitra dalam kegiatan ini juga menjadi responden atau sampel uji coba karena mereka dianggap memahami kebutuhan siswanya secara lebih spesifik sehingga pengambilan sampel dengan tujuan menggantikan siswa Sekolah Luar Biasa yang tidak bisa menguji coba secara langsung karena kondisi Pandemi COVID-19 ini bisa teratasi. Purposive sampling dilakukan agar konsentrasi sampel uji coba yang diambil adalah mereka dengan kesesuaian karakteristik yang lebih dekat dengan kebutuhan penelitian (Etikan, Musa, \& Alkassim, 2016).

Instrumen pengumpulan data berupa angket dengan skala Guttman digunakan dalam penelitian ini untuk diisi oleh para guru sebagai sampel penelitian saat uji coba. Skala guttman merupakan skala yang digunakan pada instrumen pengumpulan data yang hanya memiliki 2 pilihan jawaban yang bisa dipilih oleh subjek penelitian (Vimalrajkumar, Mathialagan, \& Sabarathnam, 2016). Penggunaan skala Guttman dalam pengukuran persepsi dan tanggapan guru terhadap alat pengembangan supaya memiliki ketegasan jawaban yang dihasilkan saat pengumpulan data uji coba dilakukan sehingga akan mempercepat teknis pelaksanaan analisis data. Setelah data uji coba terkumpul selanjutnya akan dilakukan uji Validitas dan reliabilitas angket yang digunakan. Uji Validitas dengan koefisien reprodusibilitas dan koefisien skalabilitas digunakan dalam penelitian ini sedangkan uji reliabilitas dengan rumus KuderRichardson 20.

Rumus: $\mathrm{CR}=1-(\mathrm{TE} \div \mathrm{PE})$ (Widhiarso, 2011)

Keterangan:

CR : Coefficient of Reproducibility

TE : Total Error (Jumlah eror dari seluruh responden)

PE : Potential Error (Jumlah Soal x Responden)

Rumus : CS $=1-(\mathrm{TE} \div(0,5 \times \mathrm{PE})($ Widhiarso, 2011)

Keterangan:

CS : Coefficient of Scalability

TE : Total Error (Jumlah eror dari seluruh responden)

PE : Potential Error (Jumlah Soal x Responden)

$\mathrm{r}_{\mathrm{i}} \quad=(\mathrm{k} /(\mathrm{k}-1)) \times\left(\left(\mathrm{S}_{\mathrm{t}}^{2}-\left(\sum \mathrm{p}_{\mathrm{i}} \cdot \mathrm{q}_{\mathrm{i}}\right)\right) / \mathrm{S}_{\mathrm{t}}^{2}\right)($ Sugiyono, 2014)

Keterangan:

$\mathrm{r}_{\mathrm{i}} \quad=$ Reliabilitas instrumen

$\mathrm{k} \quad=$ Banyaknya butir soal

$\mathrm{S}_{\mathrm{t}}^{2} \quad=$ Varians soal

$\mathrm{p}_{\mathrm{i}} \quad=$ Proporsi subjek yang menjawab betul pada suatu butir (mendapat skor 1 )

$\mathrm{q}_{\mathrm{i}} \quad=1-\mathrm{p}_{\mathrm{i}}$ 
Teknik analisis data deskriptif menjadi pilihan paling sesuai dalam penelitian ini untuk mendeskripsikan tanggapan sampel uji coba pada setiap tahapannya mulai dari Validasi ahli hingga uji coba produk operasional dilakukan. Dengan analisis deskriptif diharapkan pilihan tegas dari sampel uji coba dapat dijabarkan dalam deskripsi yang kesimpulannya akan menjadi masukan untuk merevisi produk pengembangan. Pelaksanaan kegiatan penelitian ini yang berlangsung pada awal bulan Maret 2020 hingga akhir bulan Juli 2020 membuat kegiatan penelitian pengembangan ini dilaksanakan dengan berbagai kendala yang dihadapi selama masa pandemi COVID-19 sehingga berbagai penyesuaian harus dilakukan untuk tetap menjaga protokol pencegahan yang harus dijalankan sesuai aturan kesehatan.

\section{HASIL DAN PEMBAHASAN}

\section{Uji Validitas Instrumen Angket Uji Coba}

Uji Validitas dilakukan dalam penelitian ini dengan menggunakan rumus koefisien reprodusibilitas dan koefisien skalabilitas. Koefisien reprodusibilitas digunakan untuk mengukur kehandalan pengukuran pada skala yang digunakan. Koefisien skalabilitas digunakan untuk mengukur apakah penyimpangan yang terjadi pada penghitungan skala reprodusibilitas dapat ditolerir sehingga instrumen dinyatakan reliabel untuk dapat digunakan. Berdasarkan hasil penghitungan nilai koefisien reprodusibilitas sebesar 0,96 serta nilai koefisien skalabilitas sebesar 0,92 diatas dapat disimpulkan bahwa instrumen pengumpulan data yang digunakan dinyatakan Valid dengan skor di atas 0,90 untuk koefisien reprodusibilitas dan skor diatas 0,80 untuk koefisien skalabilitas.

\section{Uji Reliabilitas Instrumen Angket Uji Coba}

Uji reliabilitas instrumen menggunakan uji Kuder-Richardson karena hasil penghitungan koefisien korelasi akan berada antara $0-1$ sehingga penarikan kesimpulan akan dilihat hasil penghitungan koefisien Kuder-Richardson yang harus berada pada angkat lebih besar atau sama dengan 0,6. Hasil penghitungan skor reliabilitas dengan rumus Kuder-Richardson20 diketahui sebesar 0,687073 yang artinya lebih besar dari 0,6 sehingga dapat disimpulkan bahwa instrumen pengumpulan data yang digunakan dalam penelitian ini memiliki kehandalan diatas standar sehingga dapat digunakan sebagai instrumen pengumpulan data dengan baik.

\section{Uji Validasi Ahli}

Melalui Validasi yang dilakukan oleh Dr. Muhammad Muhyi, M.Pd yang merupakan ahli bidang keolahragaan serta dosen dan asesor dari Universitas PGRI Adi Buana Surabaya menyimpulkan bahwa kedua media yang telah dikembangkan yaitu CARE Stick maupun CORE Paddle telah memadai untuk dapat dikembangkan selanjutnya sebagai upaya dalam melakukan modifikasi media pembelajaran yang ditujukan bagi siswa Sekolah Luar Biasa. Menjadi perhatian secara khusus bahwasanya pembelajaran yang diperuntukkan bagi siswa dengan berkebutuhan khusus tentunya perlu memperhatikan berbagai hal terkait lainnya seperti media pembelajaran yang akan digunakan harus menarik perhatian dengan pelbagai cara yang sesuai.

\section{Analisis Data Angket Uji Coba Awal Tongkat Estafet}

Pada uji coba ini akan dilaksanakan serupa teknisnya dengan uji coba di lapangan maupun uji coba berdasarkan pengamatan alat. Prototype tongkat estafet dengan seri 
CARE Stick 115042001 ini dikembangkan berdasarkan analisis kebutuhan dan masukan dari ahli bidang keolahragaan maka hasil desain dapat dilihat pada gambar 1 .

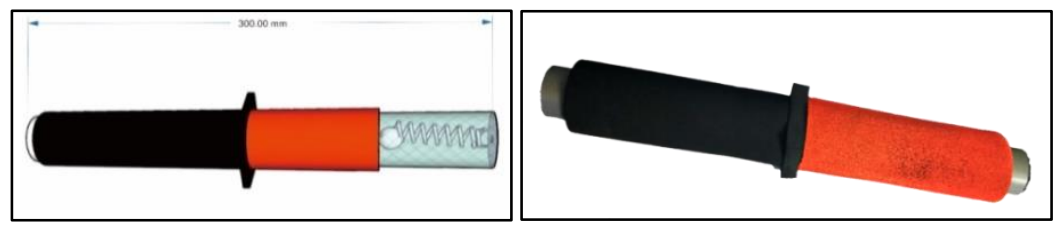

Gambar 1. Desain Gambar dan Foto Alat Prototype CARE Stick 115042001

Dalam analisis data akan dilakukan analisis deskriptif untuk menarik kesimpulan dari perilaku responden pada setiap pernyataan yang diajukan. Setelah analisis deskriptif dilakukan untuk setiap pernyataan, maka selanjutnya skor akhir angket akan dianalisis sesuai dengan kategori resiko yang telah ditentukan yaitu dengan menghitung jumlah jawaban "ya" pada setiap responden.

Tabel 1. Rekapitulasi Pernyataan Nomor 1 Uji Coba Awal Tongkat Estafet

\begin{tabular}{cccccc}
\hline & & Frequency & Percent & Valid Percent & Cumulative Percent \\
\hline \multirow{2}{*}{ Valid } & 0 & 1 & 10.0 & 10.0 & 10.0 \\
& 1 & 9 & 90.0 & 90.0 & 100.0 \\
\hline & Total & $\mathbf{1 0}$ & $\mathbf{1 0 0 . 0}$ & $\mathbf{1 0 0 . 0}$ & \\
\hline
\end{tabular}

Tabel 2. Rekapitulasi Pernyataan Nomor 2 Uji Coba Awal Tongkat Estafet

\begin{tabular}{cccccc}
\hline & & Frequency & Percent & Valid Percent & Cumulative Percent \\
\hline Valid & 1 & 10 & 100.0 & 100.0 & 100.0 \\
\hline
\end{tabular}

Tabel 3. Rekapitulasi Pernyataan Nomor 3 Uji Coba Awal Tongkat Estafet

\begin{tabular}{cccccc}
\hline & & Frequency & Percent & Valid Percent & Cumulative Percent \\
\hline \multirow{2}{*}{ Valid } & 0 & 1 & 10.0 & 10.0 & 10.0 \\
& 1 & 9 & 90.0 & 90.0 & 100.0 \\
\hline & Total & $\mathbf{1 0}$ & $\mathbf{1 0 0 . 0}$ & $\mathbf{1 0 0 . 0}$ & \\
\hline
\end{tabular}

Tabel 4. Rekapitulasi Pernyataan Nomor 4 Uji Coba Awal Tongkat Estafet

\begin{tabular}{|c|c|c|c|c|c|}
\hline & & Frequency & Percent & Valid Percent & Cumulative Percent \\
\hline \multirow{2}{*}{ Valid } & 0 & 2 & 20.0 & 20.0 & 20.0 \\
\hline & 1 & 8 & 80.0 & 80.0 & 100.0 \\
\hline & Total & 10 & 100.0 & 100.0 & \\
\hline
\end{tabular}

Tabel 5. Rekapitulasi Pernyataan Nomor 5 Uji Coba Awal Tongkat Estafet

\begin{tabular}{|c|c|c|c|c|c|}
\hline & & Frequency & Percent & Valid Percent & Cumulative Percent \\
\hline \multirow{2}{*}{ Valid } & 0 & 7 & 70.0 & 70.0 & 70.0 \\
\hline & 1 & 3 & 30.0 & 30.0 & 100.0 \\
\hline & Total & 10 & 100.0 & 100.0 & \\
\hline
\end{tabular}

Dari kelima tabel analisis deskriptif tersebut dapat disimpulkan beberapa hal bahwa dalam akumulasinya 11 tanggapan negatif atau $22 \%$ serta sebanyak 39 tanggapan positif sebesar $78 \%$ dari keseluruhan pertanyaan terhadap pengembangan media tongkat estafet. Tanggapan negatif terbesar muncul pada pertanyaan kelima dimana tercatat sebanyak 7 responden atau $70 \%$ menyatakan masih ada kekurangan dari pengembangan yang dilakukan. Sedangkan tanggapan negatif terbesar tercatat pada pertanyaan kedua 
dimana sebanyak 10 responden atau $10 \%$ menyatakan pengembangan media tongkat estafet ini masih sesuai dengan karakteristik cabang olahraga terkait. Dari uji coba awal prototype care stick seri 115042001 sesuai berbagai masukan responden disimpulkan bahwa suara lonceng yang digunakan pada tongkat estafet belum maksimal suaranya sehingga kurang menarik perhatian serta pembatas tepi tongkat seharusnya dibuat juga untuk menjaga pegangan tidak terlepas ketepi tongkat estafet.

\section{Analisis Data Angket Uji Coba Awal Bat Tenis Meja}

Pada tahapan uji coba awal lapangan maupun uji coba berdasarkan pengamatan alat yang dilakukan oleh responden dilakukan dengan teknis yang fleksibel dengan memperhatikan berbagai keterbatasan yang dihadapi. Prototype bat tenis meja dengan seri CORE Paddle 215042001 ini dikembangkan berdasarkan hasil dari tahapan analisis kebutuhan serta beberapa masukan dari ahli di bidang keolahragaan yang hasil pengembangan desainnya dapat dilihat pada gambar 2 .

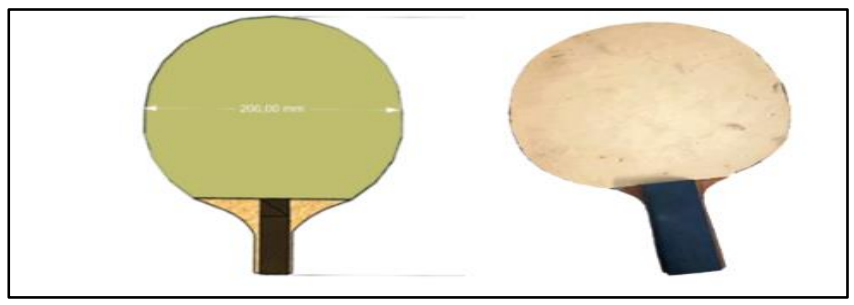

Gambar 2. Desain Gambar dan FotoPrototype CORE Paddle 215042001

Tabel 6. Rekapitulasi Pernyataan Nomor 1 Uji Coba Awal Bat Tenis Meja

\begin{tabular}{cccccc}
\hline & & Frequency & Percent & Valid Percent & Cumulative Percent \\
\hline Valid & 1 & 10 & 100.0 & 100.0 & 100.0 \\
\hline
\end{tabular}

Tabel 7. Rekapitulasi Pernyataan Nomor 2 Uji Coba Awal Bat Tenis Meja

\begin{tabular}{cccccc}
\hline & & Frequency & Percent & Valid Percent & Cumulative Percent \\
\hline Valid & 1 & 10 & 100.0 & 100.0 & 100.0 \\
\hline
\end{tabular}

Tabel 8. Rekapitulasi Pernyataan Nomor 3 Uji Coba Awal Bat Tenis Meja

\begin{tabular}{cccccc}
\hline & & Frequency & Percent & Valid Percent & Cumulative Percent \\
\hline \multirow{2}{*}{ Valid } & 0 & 2 & 20.0 & 20.0 & 20.0 \\
& 1 & 8 & 80.0 & 80.0 & 100.0 \\
\hline \multicolumn{2}{c}{ Total } & $\mathbf{1 0}$ & $\mathbf{1 0 0 . 0}$ & $\mathbf{1 0 0 . 0}$ & Total \\
\hline
\end{tabular}

Tabel 9. Rekapitulasi Pernyataan Nomor 4 Uji Coba Awal Bat Tenis Meja

\begin{tabular}{cccccc}
\hline & & Frequency & Percent & Valid Percent & Cumulative Percent \\
\hline \multirow{2}{*}{ Valid } & 0 & 3 & 30.0 & 30.0 & 30.0 \\
& 1 & 7 & 70.0 & 70.0 & 100.0 \\
\hline \multicolumn{2}{c}{ Total } & $\mathbf{1 0}$ & $\mathbf{1 0 0 . 0}$ & $\mathbf{1 0 0 . 0}$ & Total \\
\hline
\end{tabular}


Fajar Hidayatullah, Khoirul Anwar dan Ruski (2020)

Care Stick dan Core Paddle: Media Pembelajaran Pendidikan Jasmani Adaptif Untuk Siswa Disabilitas

Tabel 10. Rekapitulasi Pernyataan Nomor 5 Uji Coba Awal Bat Tenis Meja

\begin{tabular}{cccccc}
\hline & & Frequency & Percent & Valid Percent & Cumulative Percent \\
\hline \multirow{2}{*}{ Valid } & 0 & 7 & 70.0 & 70.0 & 70.0 \\
& 1 & 3 & 30.0 & 30.0 & 100.0 \\
\hline \multicolumn{2}{c}{ Total } & $\mathbf{1 0}$ & $\mathbf{1 0 0 . 0}$ & $\mathbf{1 0 0 . 0}$ & Total \\
\hline
\end{tabular}

Berdasarkan kelima tabel di atas dapat disimpulkan bahwa muncul sebanyak 12 tanggapan negatif pada alat pengembangan atau $24 \%$ dari keseluruhan jumlah tanggapan responden pada 5 pertanyaan serta 38 tanggapan positif atau $76 \%$ dari keseluruhan jumlah tanggapan responden pada 5 pertanyaan terkait. Tanggapan positif terbanyak dalam satu pertanyaan muncul pada pertanyaan pertama dan kedua yang artinya seluruh responden menanggapi positif terhadap pengembangan media pembelajaran berupa tongkat estafet telah sesuai untuk dapat digunakan sebagai media pembelajaran di sekolah terkait serta masih sesuai pula dengan karakteristik cabang olahraga tenis meja. Kesimpulan yang dihimpun dari berbagai pendapat responden ditemukan bahwa pada prototype CORE Paddle seri 215042001 bat tenis meja perlu pengembangan tambahan pada bagian busa yang nampak kurang memantul dan pegangan bat yang perlu disesuaikan lagi.

\section{Analisis Data Angket Uji Coba Utama Tongkat Estafet}

Pada uji coba ini akan dilaksanakan serupa teknisnya dengan uji coba di lapangan maupun uji coba berdasarkan pengamatan alat. Prototype tongkat estafet dengan seri CARE Stick 115042002 ini dikembangkan berdasarkan tanggapan dan evaluasi pada uji coba awal terhadap prototype tongkat estafet dengan seri CARE Stick 115042001. Setelah beberapa perabaikan dilakukan maka hasil desain prototype tongkat estafet dengan seri CARE Stick 115042002 dapat dilihat pada gambar 3.

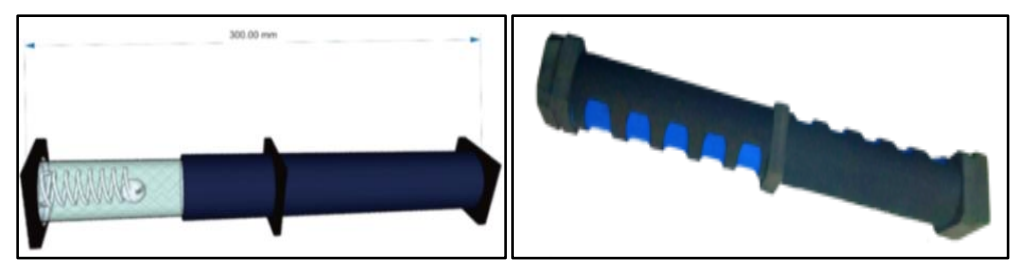

Gambar 3. Desain Gambar Prototype CARE Stick 115042002

Tabel 11. Rekapitulasi Pernyataan Nomor 1 Uji Coba Utama Tongkat Estafet

\begin{tabular}{lccccc}
\hline & & Frequency & Percent & Valid Percent & Cumulative Percent \\
\hline \multirow{2}{*}{ Valid } & 0 & 1 & 5.0 & 5.0 & 5.0 \\
& 1 & 19 & 95.0 & 95.0 & 100.0 \\
\hline \multicolumn{2}{c}{ Total } & $\mathbf{2 0}$ & $\mathbf{1 0 0 . 0}$ & $\mathbf{1 0 0 . 0}$ & Total \\
\hline
\end{tabular}

Tabel 12. Rekapitulasi Pernyataan Nomor 2 Uji Coba Utama Tongkat Estafet

\begin{tabular}{lccccc}
\hline & & Frequency & Percent & Valid Percent & Cumulative Percent \\
\hline \multirow{2}{*}{ Valid } & 0 & 1 & 5.0 & 5.0 & 5.0 \\
& 1 & 19 & 95.0 & 95.0 & 100.0 \\
\hline \multicolumn{2}{c}{ Total } & $\mathbf{2 0}$ & $\mathbf{1 0 0 . 0}$ & $\mathbf{1 0 0 . 0}$ & Total \\
\hline
\end{tabular}


Fajar Hidayatullah, Khoirul Anwar dan Ruski (2020)

Care Stick dan Core Paddle: Media Pembelajaran Pendidikan Jasmani Adaptif Untuk Siswa Disabilitas

Tabel 13. Rekapitulasi Pernyataan Nomor 3 Uji Coba Utama Tongkat Estafet

\begin{tabular}{cccccc}
\hline & & Frequency & Percent & Valid Percent & Cumulative Percent \\
\hline \multirow{2}{*}{ Valid } & 0 & 2 & 10.0 & 10.0 & 10.0 \\
& 1 & 18 & 90.0 & 90.0 & 100.0 \\
\hline \multicolumn{2}{c}{ Total } & $\mathbf{2 0}$ & $\mathbf{1 0 0 . 0}$ & $\mathbf{1 0 0 . 0}$ & Total \\
\hline
\end{tabular}

Tabel 14. Rekapitulasi Pernyataan Nomor 4 Uji Coba Utama Tongkat Estafet

\begin{tabular}{cccccc}
\hline & & Frequency & Percent & Valid Percent & Cumulative Percent \\
\hline \multirow{2}{*}{ Valid } & 0 & 3 & 15.0 & 15.0 & 15.0 \\
& 1 & 17 & 85.0 & 85.0 & 100.0 \\
\hline \multicolumn{2}{c}{ Total } & $\mathbf{2 0}$ & $\mathbf{1 0 0 . 0}$ & $\mathbf{1 0 0 . 0}$ & Total \\
\hline
\end{tabular}

Tabel 15. Rekapitulasi Pernyataan Nomor 5 Uji Coba Utama Tongkat Estafet

\begin{tabular}{cccccc}
\hline & & Frequency & Percent & Valid Percent & Cumulative Percent \\
\hline \multirow{2}{*}{ Valid } & 0 & 13 & 65.0 & 65.0 & 65.0 \\
& 1 & 7 & 35.0 & 35.0 & 100.0 \\
\hline \multicolumn{2}{c}{ Total } & $\mathbf{2 0}$ & $\mathbf{1 0 0 . 0}$ & $\mathbf{1 0 0 . 0}$ & Total \\
\hline
\end{tabular}

Terdapat 20 pendapat negatif dari total 50 tanggapan pada 5 pertanyaan yang diisi 20 responden atau sejumlah 40\%. Tanggapan negatif terbanyak terdapat pada pertanyaan nomor 5 yang artinya sebagian besar responden masih berpendapat prototype kedua ini masih perlu perbaikan. Kesimpulan yang diperoleh melalui saran pada uji coba utama pada prototype care stick seri 115042002 berbagai masukan dari responden bahwa suara lonceng yang digunakan pada tongkat estafet sudah cukup keras suaranya saat bahan inti tongkat diganti dari pipa paralon menjadi pipa aluminium serta pembatas tepi tongkat berupa sudah terpasang lengkap dengan pembatas pegangan sesuai kebutuhan.

\section{Analisis Data Angket Uji Coba Utama Bat Tenis Meja}

Selanjutnya melalui tahapan uji coba utama di lapangan maupun uji coba berdasarkan pengamatan dilakukan kepada responden dengan teknis yang tentunya tetap fleksibel dengan memperhatikan segala keterbatasan yang dihadapi saat masa pandemi. Prototype bat tenis meja pada seri CORE Paddle 215042002 dikembangkan berdasarkan hasil dari uji coba awal serta masukan dari responden dengan hasil pengembangan desainnya bisa dilihat pada gambar 4.

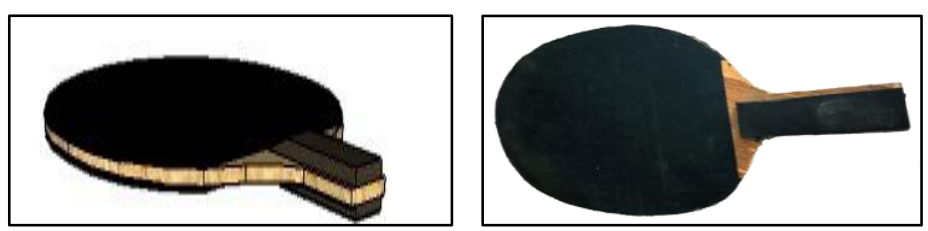

Gambar 4. Desain Gambar Prototype CORE Paddle 215042002

Tabel 16. Rekapitulasi Pernyataan Nomor 1 Uji Coba Utama Bat Tenis Meja

\begin{tabular}{cccccc}
\hline & Frequency & Percent & Valid Percent & Cumulative Percent \\
\hline Valid & 0 & 20 & 100.0 & 100.0 & 100.0 \\
\hline
\end{tabular}


Fajar Hidayatullah, Khoirul Anwar dan Ruski (2020)

Care Stick dan Core Paddle: Media Pembelajaran Pendidikan Jasmani Adaptif Untuk Siswa Disabilitas

Tabel 17. Rekapitulasi Pernyataan Nomor 2 Uji Coba Utama Bat Tenis Meja

\begin{tabular}{cccccc}
\hline & & Frequency & Percent & Valid Percent & Cumulative Percent \\
\hline \multirow{2}{*}{ Valid } & 0 & 3 & 15.0 & 15.0 & 15.0 \\
& 1 & 17 & 85.0 & 85.0 & 100.0 \\
\hline \multicolumn{2}{c}{ Total } & $\mathbf{2 0}$ & $\mathbf{1 0 0 . 0}$ & $\mathbf{1 0 0 . 0}$ & Total \\
\hline
\end{tabular}

Tabel 18. Rekapitulasi Pernyataan Nomor 3 Uji Coba Utama Bat Tenis Meja

\begin{tabular}{cccccc}
\hline & & Frequency & Percent & Valid Percent & Cumulative Percent \\
\hline \multirow{2}{*}{ Valid } & 0 & 9 & 45.0 & 45.0 & 45.0 \\
& 1 & 11 & 55.0 & 55.0 & 100.0 \\
\hline \multicolumn{2}{c}{ Total } & $\mathbf{2 0}$ & $\mathbf{1 0 0 . 0}$ & $\mathbf{1 0 0 . 0}$ & Total \\
\hline
\end{tabular}

Tabel 19. Rekapitulasi Pernyataan Nomor 4 Uji Coba Utama Bat Tenis Meja

\begin{tabular}{cccccc}
\hline & & Frequency & Percent & Valid Percent & Cumulative Percent \\
\hline Valid & 0 & 20 & 100.0 & 100.0 & 100.0 \\
\hline
\end{tabular}

Tabel 20. Rekapitulasi Pernyataan Nomor 5 Uji Coba Utama Bat Tenis Meja

\begin{tabular}{cccccc}
\hline & & Frequency & Percent & Valid Percent & Cumulative Percent \\
\hline \multirow{2}{*}{ Valid } & 0 & 12 & 60.0 & 60.0 & 60.0 \\
& 1 & 8 & 40.0 & 40.0 & 100.0 \\
\hline \multicolumn{2}{c}{ Total } & $\mathbf{2 0}$ & $\mathbf{1 0 0 . 0}$ & $\mathbf{1 0 0 . 0}$ & Total \\
\hline
\end{tabular}

Dari kelima tabel analisis deskriptif di atas diketahui bahwa terdapat 24 tanggapan negatif serta 76 tanggapan positif dari total 100 tanggapan yang berasal dari 20 responden yang menjawab 5 pertanyaan. Pertanyaan pertama terkait kesesuaian penggunaan bat tenis meja pada pembelajaran pendidikan jasmani di sekolah luar biasa terlihat seluruh responden menyatakan "ya" atau setuju dengan pertanyaan tersebut berikut pula pada pertanyaan nomor 4 menyatakan bahwa bat tenis meja yang dikembangkan aman untuk digunakan siswa berkebutuhan khusus. Sedangkan tanggapan negatif terbesar terdapat pada pertanyaan nomor 5 dengan 12 tanggapan negatif yang artinya masih banyak yang perlu diperbaiki pada prototype kedua ini. Uji coba utama untuk prototype core paddle seri 215042002 bat tenis meja dengan penambahan karet silikon sebagai lapisan penampang kepala bat dilakukan mengganti lapisan gabus yang telah dicoba sebelumnya.

\section{Analisis Data Angket Uji Coba Operasional Tongkat Estafet}

Pada uji coba tahap akhir ini akan dilaksanakan uji coba di lapangan maupun uji coba berdasarkan pengamatan alat yang dilakukan oleh guru dan staf sekolah terkait. Prototype tongkat untuk estafet seri CARE Stick 115042003 dikembangkan berdasarkan masukan serta evaluasi pada uji coba utama terhadap seri CARE Stick 115042002. Setelah beberapa perbaikan dilakukan maka hasil desain prototype tongkat estafet dengan seri CARE Stick 115042003 dapat dilihat pada gambar 6. 


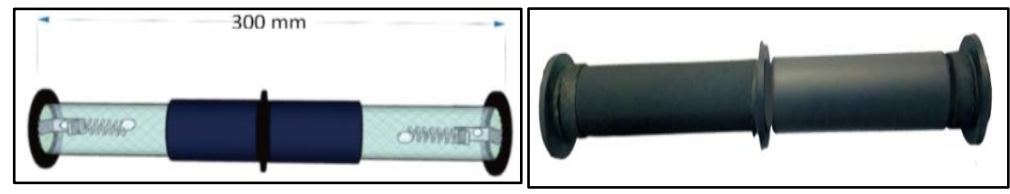

Gambar 6. Desain Gambar Prototype CARE Stick 115042003

Tabel 21. Rekapitulasi Pernyataan Nomor 1 Uji Coba Operasional Tongkat Estafet

\begin{tabular}{cccccc}
\hline & & Frequency & Percent & Valid Percent & Cumulative Percent \\
\hline Valid & 1 & 30 & 100.0 & 100.0 & 100.0 \\
\hline
\end{tabular}

Tabel 22. Rekapitulasi Pernyataan Nomor 2 Uji Coba Operasional Tongkat Estafet

\begin{tabular}{cccccc}
\hline & & Frequency & Percent & Valid Percent & Cumulative Percent \\
\hline Valid & 1 & 30 & 100.0 & 100.0 & 100.0 \\
\hline
\end{tabular}

Tabel 23. Rekapitulasi Pernyataan Nomor 3 Uji Coba Operasional Tongkat Estafet

\begin{tabular}{cccccc}
\hline & & Frequency & Percent & Valid Percent & Cumulative Percent \\
\hline Valid & 1 & 30 & 100.0 & 100.0 & 100.0 \\
\hline
\end{tabular}

Tabel 24. Rekapitulasi Pernyataan Nomor 4 Uji Coba Operasional Tongkat Estafet

\begin{tabular}{cccccc}
\hline & & Frequency & Percent & Valid Percent & Cumulative Percent \\
\hline \multirow{4}{*}{ Valid } & 0 & 1 & 3.3 & 3.3 & 3.3 \\
\cline { 2 - 6 } & 1 & 29 & 96.7 & 96.7 & 100.0 \\
\cline { 2 - 6 } & Total & $\mathbf{3 0}$ & $\mathbf{1 0 0 . 0}$ & $\mathbf{1 0 0 . 0}$ & \\
\hline
\end{tabular}

Tabel 25. Rekapitulasi Pernyataan Nomor 5 Uji Coba Operasional Tongkat Estafet

\begin{tabular}{cccccc}
\hline & & Frequency & Percent & Valid Percent & Cumulative Percent \\
\hline \multirow{4}{*}{ Valid } & 0 & 1 & 3.3 & 3.3 & 3.3 \\
& 1 & 29 & 96.7 & 96.7 & 100.0 \\
\cline { 2 - 6 } & Total & $\mathbf{3 0}$ & $\mathbf{1 0 0 . 0}$ & $\mathbf{1 0 0 . 0}$ & \\
\hline
\end{tabular}

Disimpulkan bahwa hampir seluruh tanggapan positif diberikan oleh 30 responden pada 5 pertanyaan yang diberikan. Namun dibalik tanggapan positif tersebut kami masih yakin tongkat estafet ini masih dapat dikembangkan dengan bahan yang lebih ekonomis sehingga menekan biaya produksi tanpa menghilangkan ide utamanya yaitu "care stick" tongkat estafet yang aman, menarik dan nyaman untuk digunakan siswa berkebutuhan khusus. Berdasarkan uji coba operasional tongkat estafet prototype care stick seri 115042003 dapat ditarik kesimpulan berdasarkan berbagai pendapat responden bahwa tongkat estafet yang telah dikembangkan sedemikian rupa sudah baik. Bahan yang yang digunakan sebagai pelapis berbahan busa dengan pembatas pegangan berupa karet. Berat tongkat estafet hasil pengembangan ini seberat $88 \mathrm{gr}$ sedangkan peraturan IAAF menyebutkan berat tongkat estafet tidak boleh kurang dari 50gr. Untuk panjang tongkat tetap sama $30 \mathrm{~mm}$ namun dengan diameter luar yang lebih kecil yakni sebesar $30 \mathrm{~mm}$ dari seharusnya $40 \mathrm{~mm}$ namun memiliki pembatas pegangan berdiameter $50 \mathrm{~mm}$. 


\section{Analisis Data Angket Uji Coba Operasional Bat Tenis Meja}

Selanjutnya melalui tahapan uji coba operasional di lapangan serta dilanjutkan uji coba berdasarkan pengamatan dilakukan pada responden dengan rincian teknis yang tentunya tetap memperhatikan segala keterbatasan yang harus dihadapi saat pelaksanaan kegaiatan selama masa pandemi. Prototype bat tenis meja yang dikembangan pada seri CORE Paddle 215042003 sesuai hasi uji coba utama dan masukan beberapa responden sehingga hasil pengembangannya bisa dilihat pada gambar desain serta foto berikut ini.
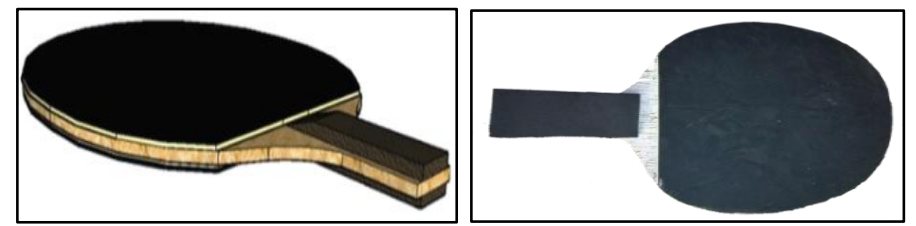

Gambar 71. Desain Gambar Prototype CORE Paddle 215042003

Tabel 27. Rekapitulasi Pernyataan Nomor 1 Uji Coba Operasional Bat Tenis Meja

\begin{tabular}{cccccc}
\hline & & Frequency & Percent & Valid Percent & Cumulative Percent \\
\hline Valid & 1 & 30 & 100.0 & 100.0 & 100.0 \\
\hline
\end{tabular}

Tabel 28. Rekapitulasi Pernyataan Nomor 2 Uji Coba Operasional Tongkat Estafet

\begin{tabular}{cccccc}
\hline & Frequency & Percent & Valid Percent & Cumulative Percent \\
\hline Valid & 1 & 30 & 100.0 & 100.0 & 100.0 \\
\hline
\end{tabular}

Tabel 29. Rekapitulasi Pernyataan Nomor 3 Uji Coba Operasional Tongkat Estafet

\begin{tabular}{cccccc}
\hline & & Frequency & Percent & Valid Percent & Cumulative Percent \\
\hline \multirow{4}{*}{ Valid } & 0 & 3 & 10.0 & 10.0 & 10.0 \\
& 1 & 27 & 90.0 & 90.0 & 100.0 \\
\cline { 2 - 6 } & Total & $\mathbf{3 0}$ & $\mathbf{1 0 0 . 0}$ & $\mathbf{1 0 0 . 0}$ & \\
\hline
\end{tabular}

Tabel 30. Rekapitulasi Pernyataan Nomor 4 Uji Coba Operasional Tongkat Estafet

\begin{tabular}{cccccc}
\hline & & Frequency & Percent & Valid Percent & Cumulative Percent \\
\hline \multirow{4}{*}{ Valid } & 0 & 1 & 3.3 & 3.3 & 3.3 \\
& 1 & 29 & 96.7 & 96.7 & 100.0 \\
\cline { 2 - 6 } & Total & $\mathbf{3 0}$ & $\mathbf{1 0 0 . 0}$ & $\mathbf{1 0 0 . 0}$ & \\
\hline
\end{tabular}

Tabel 31. Rekapitulasi Pernyataan Nomor 5 Uji Coba Operasional Tongkat Estafet

\begin{tabular}{cccccc}
\hline & & Frequency & Percent & Valid Percent & Cumulative Percent \\
\hline \multirow{4}{*}{ Valid } & 0 & 5 & 16.7 & 16.7 & 16.7 \\
& 1 & 25 & 83.3 & 83.3 & 100.0 \\
\cline { 2 - 6 } & Total & $\mathbf{3 0}$ & $\mathbf{1 0 0 . 0}$ & $\mathbf{1 0 0 . 0}$ & \\
\hline
\end{tabular}

Melalui kelima tabel analisis deskriptif diatas diketahui bahwa dari total 150 tanggapan yang berasal dari 30 responden nampak terdapat 9 tanggapan negatif atau $6 \%$ serta 141 tanggapan positif atau 94\%. Pada pertanyaan pertama dan kedua seluruhnya menunjukkan tanggapan positif yaitu 30 responden sepakat bahwa bat tenis meja yang 
dikembangkan telah sesuai untuk diguakan dalam pembelajaran pendidikan jasmani di sekolah luar biasa dengan masih memenuhi karakteristik cabang olahraga terkait. 5 tanggapan negatif pada pertanyaan nomor 5 menunjukkan masih ada peluang untuk bat tenis meja hasil pengembangan ini dilanjutkan dalam penelitian selanjutnya. Pada uji coba operasional untuk prototype core paddle seri 215042003 bat tenis meja dikembangkan dari prototype sebelumnya dengan menggabungkan antara lapisan busa dan lapisan silikon rubber untuk melapisi kepala bat. Penggabungan kedua bahan ini sesuai pendapat responden yang melakukan uji coba alat disimpulkan bahwa telah sangat sesuai untuk menambah pantulan pada bat tenis meja yang hanya berbahan papan pada bagian intinya. Namun tepian bat yang dibuat secara manual ini nampaknya perlu lebih dirapikan lagi hingga tampilannya lebih bagus untuk dilihat daripada sebelumnya. Untuk bat tenis meja standarnya berada pada berat $150 \mathrm{gr}-250 \mathrm{gr}$, sedangkan bat hasil pengembangan memiliki berat $209 \mathrm{gr}$, namun dengan luas penampang yang lebih lebar.

Beberapa penelitian sebelumnya telah dilakukan untuk mengembangkan alat olahraga bagi disabilitas walaupun terkadang belum secara spesifik sesuai dengan program pengembangan olahraga yang dibutuhkan. Alat olahraga yang disesuaikan dengan kebutuhan khusus menjadi beberapa hal yang dikembangkan di beberapa negara walaupun belum secara spesifik dan sesuai dengan program pengembangan olahraga (Hancock, Lyras, \& Ha, 2013). Sebuah prestasi olahraga yang juga dimulai dalam pembelajaran pendidikan jasmani di sekolah termasuk Sekolah Luar Biasa patut menjadi salah satu perhatian dalam pengembangannya dengan didukung sarana dan fasilitas olahraga yang memadai dan sesuai secara khusus dengan kebutuhan siswa Sekolah Luar Biasa. Tidak akan ada keniscayaan dalam prestasi olahraga, yang ada adalah ketersediaan perlengkapan dan fasilitas yang sesuai kebutuhan dan pengembangannya secara ilmiah (Christopher, Okakah, \& Gabriel, 2015). Pada penelitian sebelumnya tongkat estafet juga dapat dimodifikasi dengan bentuk berupa bola plastik yang digunakan untuk siswa tunagrahita ringan (Wahyu \& Tuasikal, 2016).

Hasil pengembangan dalam penelitian ini tentunya memiliki berbagai batasan yang perlu diketahui sebelumnya terutama saat hasil penelitian ini akan diadopsi untuk diterapkan pada sekolah lain. Batasan yang pertama adalah hasil pengembangan dalam penelitian ini paling sesuai digunakan untuk siswa Sekolah Luar Biasa Negeri Keleyan sehingga saat akan digunakan di sekolah lain maka akan perlu penelitian lebih lanjut mengingat karakteristik sekolah tersebut kemungkinan akan berbeda. Pengembangan yang dilakukan dalam penelitian ini juga hanya sebatas pengembangan tongkat estafet dan bat tenis meja sesuai permasalahan yang dihadapi siswa sekolah terkait yang ditemukan saat dilakukan analisis kebutuhan.

\section{KESIMPULAN}

Hasil pengembangan tongkat estafet dengan seri care stick 115042003 telah dihasilkan dengan berbahan aluminium pada bagian dalamnya serta bagian luar tongkat yang lebih empuk sebagai keamanan serta pembatas pegangan pada bagian tengah dan tepi tongkat agar tidak terlepas dari genggaman terutama pada siswa tunadaksa. Hal ini sesuai dengan kebutuhan mitra akan tongkat estafet yang aman digunakan, menarik perhatian dan nyaman digunakan untuk siswa pada berbagai kategori kebutuhan khusus. Untuk hasil pengembangan bat tenis meja core paddle 215042003 dengan bahan yang ringan dan ukuran yang diperbesar. Kendala penggunaan bahan gabus pelapis dan karet silicon digunakan untuk mengatasi ketiadaan karet dengan ukuran sesuai karena pada umumnya karet bat tenis meja hanya berukuran standar. Sebagai rekomendasi dapat 
dilakukan pengembangan secara berkelanjutan ke depannya untuk terus meningkatkan kesesuaian media pembelajaran pendidikan jasmani dengan berbagai keterbatasan.

\section{DAFTAR PUSTAKA}

Aka, K. A. (2019). Integration Borg and Gall (1983) and Lee \& Owen (2004) Model As An Alternative Model of Designed-Based Research of Interactive Multimedia in Elementary School. Journal of Physics: Conference Series, Volume 1318, Seminar on Advances in Mathematics, Science and Engineering for elementary School (SAMSES 2018) (pp. 1-8). Yogyakarta: IOP Publishing.

Ardiansyah, W., \& Tuasikal, A. R. (2016). Modifikasi Permainan Lari Estafet Untuk Meningkatkan Gerak Manipulatif Anak Tunagrahita Ringan. Jurnal Pendidikan Olahraga dan Kesehatan, 4(1), 177-184.

Bano, H., Akhter, N., \& Anjum, N. (2013). Analysis of Educational Facilities and Opportunities for Students with Special Needs at University of the Punjab. Journal of Educational Research, 16(1), 1-14.

Bhat, A., Landa, R., \& Galloway, J. (2011). Current perspectives on motor functioning in infants, children, and adults with autism spectrum disorder. Physical Therapy, 91(7), 1116-1129. https://doi.org/10.2522/ptj.20100294

Chhabra, S., Srivastava, R., \& Srivastava, I. (2010). Inclusive education in Botswana: The perceptions of school teachers. Journal of Disability Policy Studies, 20(4), 219228. https://doi.org/10.1177/1044207309344690

Christopher, I. A., Okakah, R. O., \& Gabriel, A. (2015). Facilities/Equipment as Predictor of Sport Development in Edo State Nigeria. Europan Journal of Research in Social Sciences, 3(3), 61-67.

Depdikbud. (1993). Kurikulum Sekolah Dasar: Garis-Garis Besar Program Pengajaran Mata Pelajaran Pendidikan Jasmani. Jakarta: Depdikbud.

Devine, A., Carrol, A., Naivalu, S., Seru, S., Baker, S., Bayak-Bush, B., James, K., Larcombe, L., Brown, T., \& Marella, M. (2017). They don't see my disability anymore'-The outcomes of sport for development programmes in the lives of people in the Pacific. Journal of Sport for Development, 5(8), 4-18.

Erianti, \& Sari, D. N. (2018). Developing Learning Media of Adaptive Sport Course in SLB Negeri 2 Padang. Journal of Educational Research and Evaluation, 2(3), 133140. http://dx.doi.org/10.23887/jere.v2i3.15676

Etikan, I., Musa, S. A., \& Alkassim, R. S. (2016). Comparison of Convenience Sampling and Purposive Sampling. American Journal of Theoretical and Applied Statistics, 5(1), 1-4. 
Foley, J. T., Tindal, D., Lieberman, L., \& Kim, S.-Y. (2007). How to Develop Disability Awareness Using the Sport Education Model. JOPERD: Journal of Physical Education, Recreation and Dance, 78(9), 32-36. https://doi.org/10.1080/07303084.2007.10598096

Friend, M. P., \& Bursuck, W. D. (2012). Including students with special needs: A practical guide for classroom teachers (6th ed.). Upper Saddle River, New Jersey: Pearson.

Hancock, M. G., Lyras, A., \& Ha, J. P. (2013). Sport for Development Programs for Girls and Women: A Global Assessment. Journal of Sport for Development, 15-24.

Hettiaarachi, S., Ranaweera, M., Walisundara, D., Daston-Attanayake, L., \& Das, A. K. (2018). Including all? Perceptions of Mainstream Teachers on Inclusive Education in the Western Province of Sri Lanka. International Journal of Special Education, $33(2), 427-447$.

Jeoung, B. (2018). Motor proficiency differences among students with intellectual disabilities, autism, and developmental disability. Journal of Exercise Rehabilitation, 14(2), 275-281. 10.12965/jer.1836046.023

Kielhofner, G., \& Miyake, S. (1981). The Therapeutic Use of Games with Mentally Retarded Adults. American Journal of Occupational Therapy, 35, 375-382. https://doi.org/10.5014/ajot.35.6.375

Kızar, O., Dalkılıç, M., Uçan, İ., Mamak, H., \& Yiğit, Ş. (2015). The importance of sports for disabled children. Merit Research Journal of Art, Social Science and Humanities, 3(5), 58-61.

Lastuka, A., \& Cottingham, M. (2015). The effect of adaptive sports on employment among people with Disabilities. Disability and Rehabilitation, 38(8), 1-7. https://doi.org/10.3109/09638288.2015.1059497

Liu, T., \& Breslin, C. M. (2013). Fine and gross motor performance of the MABC-2 by children with autism spectrum disorder and typically developing children. Research in Autism Spectrum Disorders, 7(10), 1244-1249. https://doi.org/10.1016/j.rasd.2013.07.002

MacDonald, M., Lord, C., \& Ulrich, D. A. (2014). Motor skills and calibrated autism severity in young children with autism spectrum disorder. Adapted Physical Activity Quarterly, 31(2), 95-105. https://doi.org/10.1123/apaq.2013-0068

Martika, T. (2020). Improving Sensorimotor of Children with Intellectual Disability Through Teaching Writing in Shanti Yoga Special School, Klaten Central Java. Indonesian Journal of Disability Studies (IJDS), 7(1), 101-105. http://dx.doi.org/10.21776/ub.ijds.2019.007.01.11 
Morley, D., Bailey, R., Tan, J., \& Cooke, B. (2005). Inclusive Physical Education: teachers' views of including pupils with Special Educational Needs and/or disabilities in Physical Education. European Physical Education Review, 11(1), 84107. https://doi.org/10.1177/1356336X05049826

Oswald, M., \& Swart, E. (2011). Addressing South African pre-service teachers' sentiments, attitudes and concerns. International Journal of Disability Development and Education, 58(3), 287-302. https://doi.org/10.1080/1034912X.2011.626665

Pappas, M. A., Papoutsi, C., \& Drigas, A. S. (2018). Policies, Practices, and Attitudes toward Inclusive Education: The Case of Greece. Social Sciences, 7(6), 1-15. https://doi.org/10.3390/socsci7060090

Staples, K. L., \& Reid, G. (2010). Fundamental movement skills and autism spectrum disorders. Journal of Autism and Developmental Disorders, 40(2), 209-217. https://doi.org/10.1007/s10803-009-0854-9

Sugiyono. (2014). Statistika Untuk Penelitian. Bandung: Alfabeta.

Vimalrajkumar, N., Mathialagan, P., \& Sabarathnam, V. E. (2016). Developing a Guttman Scale for Measuring The Degree of Empowerment of Rural Women. International Journal of Applied Research, 2(3), 195-201.

Wahyu, A., \& Tuasikal, A. R. (2016). Modifikasi Permainan Lari Estafet Untuk Meningkatkan Gerak Dasar (Studi pada SDLB Merdeka Kecamatan Candi Kabupaten Sidoarjo). Jurnal Pendidikan Olahraga dan Kesehatan, 4(1), 177-184.

Widhiarso, W. (2011). SKALO: Program Analisis Skala Guttman. Yogyakarta: Fakultas Psikologi Universitas Gajah Mada. 